Environment Conservation Journal 14(3)23-27, 2013

ISSN 0972-3099 (Print) 2278-5124 (Online)

Abstracted and Indexed

\title{
Assessment of indoor SPM in kitchens of household using different modes of cooking in Jammu, India
}

\author{
Raj Kumar Rampal $\bowtie$ and Anjana Chib
}

Received: 21.02 .2013

Accepted: 11.7.2013

\begin{abstract}
The present study has been carried out to assess indoor SPM levels in kitchens of the household using different modes of cooking in Jammu using handy air sampler (Envirotech APM 821) with air flow rate of 1.5 LPM from 6am to $2 \mathrm{pm}$. All the kitchens with different modes of cooking exhibited values of indoor SPM higher than the prescribed CPCB values of $200 \mu \mathrm{g} / \mathrm{m}^{3}$. Complied average values of SPM were used to calculate IPI (Indoor Pollution Index). The calculated values of indoor SPM in all the four types of kitchens were observed to be statistically significant $(p<0.05)$.
\end{abstract}

Keywords: assessment, indoor air pollution, SPM, indoor pollution index

\section{Introduction}

Indoor air pollution is the fourth-leading cause of premature death in the developing world. Women and their small children are at increased risk due to the amount of time spent close to the stove in the kitchen. Indoor air pollution was responsible for more than 1.6 million annual deaths and $2.7 \%$ of global burden of diseases (WHO, 2006). Indoor air pollution from solid fuel use is the tenth largest threat to public health (WHO, 2007a). Hence, exposure to indoor air pollution from the combustion of biofuels is a significant public health hazard predominately affecting the poor in both rural and urban communities in developing countries. There is strong evidence that smoke from biofuels can cause acute lower respiratory infection in childhood. (Fullerton et al. 2008, WHO 2006, 2007b, Smith et al. 2000, 2004, Smith and Mehta, 2003).Indoor air pollution from the burning of solid fuels kills over 1.6 million people predominately women and children each year. This is more than three people per minute. It is a death toll almost as great as that caused by unsafe water and sanitation and greater than that caused by malaria. Women are two to four times more likely to suffer chronic obstructive pulmonary disease (COPD) when exposed to indoor smoke pollution. Some studies suggested that women who cook over indoor wood

\section{Author's Address}

Department of Environmental Sciences,

University of Jammu (J\&K)

Email: rajkrampal@gmail.com fires were 2.5 times more likely to have active tuberculosis (Warwick and Doig, 2004).In the present study attempt has been made to assess indoor SPM levels in kitchen of the households using different modes of cooking in Jammu so as to propose suggestive measures regarding indoor air pollution abatement strategies.

\section{Material and Methods}

The study area was divided into four zones to cover all the households using different modes of cooking in the kitchens i.e Zone I (HL- Household using LPG in the kitchen), Zone II (HH- Household using electric heater in the kitchen), Zone III (HFHousehold using fuelwood in the kitchen) and Zone IV (HK- Household using kerosene oil in the kitchen). Five households were selected randomly and in each household sampling of air was done thrice to determine indoor SPM using handy air sampler (Envirotech APM 821) with air flow rate of 1.5 LPM.The sampling was done eight hourly. (6am to 2pm).The SPM was trapped on the preweighed oven dried glass Millipore micro-fiber filter paper attached to the tube assembly of air sampler. Precisa balance was used for weighing the filter paper before and after sampling.

The SPM in $\mu \mathrm{g} / \mathrm{m}^{3}$ was calculated using following formula. 
Where, $\mathrm{W}_{2}$ and $\mathrm{W}_{1}=$ Final and Initial weights of filter paper $\mathrm{V}=$ Volume of air in litres

$F_{1}$ and $F_{2}=$ Initial and final rates of air flow in LPM which was converted into $\mathrm{m}^{3} / \mathrm{min}$ using conversion formula.

$$
1 \mathrm{LPM}=10^{-3} \mathrm{~m}^{3} / \mathrm{min}
$$

$\mathrm{T}=$ Time of sampling in minutes

Complied average values of SPM were used to calculate IPI using formula (Moghissi, 1991)

IPI $=1 / n\left(C_{1} / L_{1}+C_{2} / L_{2} \ldots \ldots \ldots . . C_{n} / L_{n}\right)$

Where, IPI $=$ Indoor Pollution Index

$\mathrm{C}=$ Concentration of pollutants

$\mathrm{L}=$ Concentration limit for pollutants

$\mathrm{n}=$ no. of pollutants included in the computation

The ranges used were

$$
\begin{array}{ll}
0.0 & -0.1-\text { Good } \\
0.1 & -0.2 \text { - Moderate } \\
0.2 & -0.4 \text {-Unhealthy } \\
0.3 & \text { and above -Hazardous }
\end{array}
$$

\section{Results and disscusion}

The analysis of indoor SPM data of households using different modes of cooking in the kitchens revealed that kitchen using fuelwood i.e Zone III (HF) exhibited maximum average indoor SPM of $1435.54 \pm 849.47 \mu \mathrm{g} / \mathrm{m}^{3}$ with a range of 617.28 $3456.79 \mu \mathrm{g} / \mathrm{m}^{3}$ followed by Zone IV (HK) i.e kitchen using kerosene oil which exhibited average indoor SPM of $710.06 \pm 180.37 \mu \mathrm{g} / \mathrm{m}^{3}$ with a range of $549.45-1098.90 \mu \mathrm{g} / \mathrm{m}^{3}$ (Table 1). (Balakrishnan et al. 2002) also observed concentration of respirable particulate matter to be ranged from 500 - $2000 \mu \mathrm{g} / \mathrm{m}^{3}$ during cooking in biomass using households in four districts of Tamil Nadu.Jiang and Bell (2008) also made conclusion that biomass burning for cooking contributed substantially to indoor particulate levels in urban and sub-urban households in North - Eastern China.Lim and Seow (2012) also reported that particulate matter emissions from biomass fuel far exceeded the recommended safe limit. The kitchen using LPG i.e Zone I (HL) exhibited average indoor SPM of $376.79 \pm 140.98 \mu \mathrm{g} / \mathrm{m}^{3}$ with a range of 154.32 $641.02 \mu \mathrm{g} / \mathrm{m}^{3}$ and minimum average indoor SPM of $262.08 \pm 95.90 \mu \mathrm{g} / \mathrm{m}^{3}$ with a range of 155.27$480.76 \mu \mathrm{g} / \mathrm{m}^{3}$ was exhibited by Zone II $(\mathrm{HH})$ i.e kitchen using electric heater as mode of cooking. Rollin et al. (2004) also observed that the proportion of dwellings with a detectable 24-h concentration of RSP (Respirable suspended particulate) was significantly higher in unelectified $(48.1 \%)$ than electrified dwellings $(24.5 \%)$ i.e introduction of electricity for cooking has significantly reduced RSP (Respirable suspended particulate) in kitchen. But at same time all the kitchens with different modes of cooking exhibited values of indoor SPM higher than the prescribed CPCB values of $200 \mu \mathrm{g} / \mathrm{m}^{3}$ (Table 1). Mohan et al. (1992) also observed values of indoor RSPM above the prescribed levels. Cattaneo et al. (2011)also reported exceeded indoor $\mathrm{PM}_{10}$ levels than recommended guidelines in 600 homes in the Lodi province Italy. The critical analysis of compiled data of different kitchens of the study area revealed that LPG using kitchen with electrical chimney fitted ventilators exhibited minimum indoor SPM of $230.15 \pm 90.14 \mu \mathrm{g} / \mathrm{m}^{3}$ with a range of $166.66-$ $333.33 \mu \mathrm{g} / \mathrm{m}^{3}$ followed by LPG using kitchen with exhaust fan fitted ventilator exhibited average indoor SPM of $390.096 \pm 119.54 \mu \mathrm{g} / \mathrm{m}^{3}$ with a range of $154.32-501.67 \mu \mathrm{g} / \mathrm{m}^{3}$ whereas the LPG using kitchen with ventilator without exhaust fan exhibited higher value of $483.51 \pm 153.97 \mu \mathrm{g} / \mathrm{m}^{3}$ with a range of $333.33-641.02 \mu \mathrm{g} / \mathrm{m}^{3}$. From this critical analysis of the data it can be clearly concluded that ventilators with improved mechanical devices for the removal of emissions during cooking played significant role in the abatement of indoor SPM in the kitchens as well as households.Though all the three types of LPG using kitchens exhibited indoor SPM levels above the prescribed limits of $200 \mu \mathrm{g} / \mathrm{m}^{3}$ as laid down by CPCB. The critical analysis of complied data further revealed that electric heater using kitchen with exhaust fan fitted ventilators exhibited lowest indoor SPM $\left(160.25 \mu \mathrm{g} / \mathrm{m}^{3}\right)$ within the prescribed limits and electric heaterusing kitchen with ventilator without exhaust fan exhibited higher values of indoor SPM $\left(276.55 \pm 65.35 \mu \mathrm{g} / \mathrm{m}^{3}\right)$ 
whereas electric heater using kitchens without the prescribed limits of CPCB and further conclude ventilator exhibited highest indoor SPM $(320.5 \pm$ that mechanical ventilators remove emissions more $160.25 \mu \mathrm{g} / \mathrm{m}^{3}$ ) and both these values were above efficiently.

Table 1: Average indoor SPM in kitchens of study area

\begin{tabular}{|c|c|c|c|c|}
\hline House No. & $\begin{array}{l}\text { Average indoor } \\
\mathrm{SPM}\left(\mu \mathrm{g} / \mathrm{m}^{3}\right) \text { in } \\
\text { kitchen using } \\
\text { LPG(Zone } \mathrm{HL})\end{array}$ & $\begin{array}{l}\text { Average indoor SPM } \\
\left(\mu \mathrm{g} / \mathrm{m}^{3}\right) \text { in kitchen } \\
\text { using electric heater } \\
(\text { Zone } \mathrm{HH})\end{array}$ & $\begin{array}{l}\text { Average indoor } \\
\text { SPM }\left(\mu \mathrm{g} / \mathrm{m}^{3}\right) \text { in } \\
\text { kitchen using } \\
\text { fuelwood } \\
\text { (Zone HF) }\end{array}$ & $\begin{array}{l}\text { Average indoor } \\
\text { SPM }\left(\mu \mathrm{g} / \mathrm{m}^{3}\right) \text { in } \\
\text { kitchen using } \\
\text { kerosene (Zone } \\
\text { HK) }\end{array}$ \\
\hline House No. 1 & $\begin{array}{l}483.51 \pm 153.97 \\
(333.33-641.02)\end{array}$ & $\begin{array}{l}265.92 \pm 83.75 \\
(170.94-329.21)\end{array}$ & $\begin{array}{l}2644.03 \pm 740.95 \\
(2006.17-3456.79)\end{array}$ & $\begin{array}{l}827.83 \pm 107.92 \\
(761.9-952.38)\end{array}$ \\
\hline House No. 2 & $\begin{array}{l}423.38 \pm 99.37 \\
(308.64-480.76)\end{array}$ & $\begin{array}{l}258.79 \pm 89.65 \\
(155.27-310.55)\end{array}$ & $\begin{array}{l}1581.90 \pm 495.19 \\
(1010.1-1867.81)\end{array}$ & $\begin{array}{l}572.92 \pm 92.98 \\
(480.7-666.66)\end{array}$ \\
\hline House No.3 & $\begin{array}{l}421.41 \pm 87.83 \\
(320.51-480.76)\end{array}$ & $160.25 \pm 0.00$ & $\begin{array}{l}1561.64 \pm 841.49 \\
(1005.74-2529.76)\end{array}$ & $\begin{array}{l}866.91 \pm 284.52 \\
(549.45-1098.90)\end{array}$ \\
\hline House No.4 & $\begin{array}{l}325.5 \pm 173.72 \\
(154.32-501.67)\end{array}$ & $\begin{array}{l}304.94 \pm 13.47 \\
(297.16-320.5)\end{array}$ & $\begin{array}{l}695.06 \pm 95.23 \\
(617.23-801.28)\end{array}$ & $\begin{array}{l}596.14 \pm 100.74 \\
(480.76-666.66)\end{array}$ \\
\hline House No.5 & $\begin{array}{l}230.15 \pm 90.14 \\
(166.66-333.33)\end{array}$ & $\begin{array}{l}320.5 \pm 160.25 \\
(160.25-480.76)\end{array}$ & $\begin{array}{l}695.06 \pm 95.23 \\
(617.23-801.28) \\
\end{array}$ & $\begin{array}{l}686.52 \pm 100.08 \\
(617.28-801.28) \\
\end{array}$ \\
\hline $\begin{array}{l}\text { Average indoor } \\
\operatorname{SPM}\left(\mu \mathrm{g} / \mathrm{m}^{3}\right)\end{array}$ & $\begin{array}{l}376.79 \pm 140.98 \\
(154.32-641.02)\end{array}$ & $\begin{array}{l}262.08 \pm 95.90 \\
(155.27-480.76)\end{array}$ & $\begin{array}{l}1435.54 \pm 849.47 \\
(617.28-3456.79)\end{array}$ & $\begin{array}{l}710.06 \pm 180.37 \\
(549.45-1098.90)\end{array}$ \\
\hline
\end{tabular}

On the comparative basis the fuelwood using kitchens without ventilator exhibited three fold higher values $\left(1929.19 \pm 814.30 \mu \mathrm{g} / \mathrm{m}^{3}\right)$ of indoor SPM as compared with that of $(695.07 \pm$ $85.17 \mu \mathrm{g} / \mathrm{m}^{3}$ ) fuelwood using kitchen with ventilator without exhaust fan. This signifies the importance of ventilators. Murray et al. (2012) observed that biomass cooking fuels were an important risk factor for ALRI (Acute Lower Respiratory Infection) beside the influence of natural household ventilation conditions. The critical compilation of data revealed that the kerosene oil using kitchens without ventilator exhibited higher value (776.715 $\left.\pm 214.82 \mu \mathrm{g} / \mathrm{m}^{3}\right)$ of indoor SPM as compared with that $\left(665.63 \pm 150.03 \mu \mathrm{g} / \mathrm{m}^{3}\right)$ of kerosene oil using kitchen with ventilator without exhaust fan which further signifies the importance of ventilation.The calculation of Indoor Air Pollution Index (IPI) for only SPM for all the kitchens of study area rated values well above 0.4 i.e 1.88 for LPG using kitchen, 1.31 for electric heater using kitchen, 7.17 for fuelwood using kitchen, 3.55 for kerosene oil using kitchen and all these values were read off as 'hazardous' (Table 2). The statistical analysis of data of average indoor SPM using T-test revealed
Table 2: Indoor Pollution Index (IPI) for SPM

\begin{tabular}{|c|c|c|}
\hline $\begin{array}{c}\text { Zone/ } \\
\text { Type of kitchen }\end{array}$ & IPI for SPM & Status \\
\hline $\begin{array}{c}\text { Zone HL } \\
\text { kitchen using } \\
\text { LPG) }\end{array}$ & 1.88 & Hazardous \\
\hline $\begin{array}{c}\text { Zone HH } \\
\text { (kitchen using }\end{array}$ & 1.31 & Hazardous \\
\hline $\begin{array}{c}\text { Zoctric Heater) } \\
\text { (kitchen using } \\
\text { Fuelwood) }\end{array}$ & 7.17 & Hazardous \\
\hline $\begin{array}{c}\text { Zone HK } \\
\text { (kitchen using } \\
\text { Kerosene oil) }\end{array}$ & 3.55 & Hazardous \\
\hline
\end{tabular}

that all the differences in the values of average indoor SPM in all the four types studied kitchens were significant $(\mathrm{p}<0.05)$ (Table 3$)$. 
Rampal and Chib

Table 3: T-Test: paired two samples for means of SPM.

\begin{tabular}{|c|c|c|c|c|}
\hline & Mean Difference & Std. deviation & $\begin{array}{c}\text { Sig. 2-tailed } \\
(\mathbf{p})\end{array}$ & $\begin{array}{c}\text { Statistical } \\
\text { Value(p<0.05) }\end{array}$ \\
\hline LPG -Electric heater & 114.71 & 179.17 & 0.026 & Significant \\
\hline LPG -Fuelwood & -1058.75 & 812.73 & .000 & Significant \\
\hline LPG - Kerosene oil & -333.27 & 207.33 & .000 & Significant \\
\hline $\begin{array}{c}\text { Electric heater - } \\
\text { Kerosene oil }\end{array}$ & -447.99 & 224.24 & .000 & Significant \\
\hline \begin{tabular}{c} 
Fuelwood-Kerosene oil \\
\hline $\begin{array}{c}\text { Fuelwood-Electric } \\
\text { heater }\end{array}$
\end{tabular} & 725.47 & 817.25 & .004 & Significant \\
\hline
\end{tabular}

Overall from the above analysis, it is concluded

- Households with fuelwood using kitchens without ventilators exhibited maximum concentration of SPM $\left(1929.19 \pm 814.30 \mu \mathrm{g} / \mathrm{m}^{3}\right)$

- Households with electric heater using kitchen with exhaust fan fitted ventilators exhibited minimum concentration of SPM $\left(160.25 \mu \mathrm{g} / \mathrm{m}^{3}\right)$

- Within the households with LPG using kitchens, the kitchens with electric chimney exhibited minimum value of SPM $\left(230.15 \pm 90.14 \mu \mathrm{g} / \mathrm{m}^{3}\right)$

- With same conditions of ventilation i.e kitchens with ventilators without exhaust fan the fuelwood using kitchens exhibited highest value of indoor SPM i.e $695.07 \pm 85.17 \mu \mathrm{g} / \mathrm{m}^{3}$ followed by kerosene oil using kitchen exhibiting value of $665.63 \pm 150.03 \mu \mathrm{g} / \mathrm{m}^{3}$, LPG using kitchen exhibiting value of $483.51 \pm 153.97 \mu \mathrm{g} / \mathrm{m}^{3}$ and lowest value of $276.55 \pm 65.35 \mu \mathrm{g} / \mathrm{m}^{3}$ was exhibited by heater using kitchen.

- With same mode of cooking with different conditions of ventilation electric heater using kitchen without ventilator exhibited highest value of indoor SPM $\left(320.5 \pm 160.25 \mu \mathrm{g} / \mathrm{m}^{3}\right)$ followed by electric heater using kitchen with ventilator without exhaust fan exhibiting value of $276.55 \pm 65.35 \mu \mathrm{g} / \mathrm{m}^{3}$ and lowest SPM of $160.25 \mu \mathrm{g} / \mathrm{m}^{3}$ was exhibited by heater using kitchen with exhaust fan fitted ventilator.
- All the kitchens with different modes of cooking exhibited values of indoor SPM higher than the prescribed CPCB values of $200 \mu \mathrm{g} / \mathrm{m}^{3}$

\section{Suggestive measures}

The concentration of indoor air pollutants can be reduced by the use of

- improved cooking stoves,

- use of smoke hoods, chimney stoves,

- better behavioural practices such as using dried wood, use of smaller size fuelwood, use of lidsduring cooking, use of pressure cooker to reduce cooking time,

- regular maintenance of the stove, chimney and hood,

- use of cheap and clean sources for cooking such as biogas,

- well ventilated kitchens.

With these approaches, the indoor air pollution can be reduced thereby decreasing the risk of health hazards to the people.

\section{References}

Balakrishnan, K., J. Parikh, S. Sankar, R. Padmavathi, K. Srividya, V. Venugopal, S. Prasad and V.L. Pandey 2002. Daily Average Exposures to Respirable Particulate Matter from Combustion of Biomass Fuels in Rural Households of Southern India. Environmental Health Perspectives, 110(11): 1069-1075. 
Cattaneo, A., C. Peruzzo, G. Garramone, P. Urso, R. Ruggeri, P. Carrer and D.M. Cavallo 2011. Airborne particulate matter and gaseous air pollutants in residential structures in Lodi province, Italy.Indoor Air, 21(6): 489-500.

*Fullerton, D.G., N. Bruce and S.B. Gordon 2008. Indoor air pollution from biomass fuel smoke is a major health concern in the developing world. Transactions of the Royal Society of Tropical Medicine and Hygiene ,102(9): 843-851.

Jiang, R. and M. L. Bell 2008. A Comparison of Particulate Matter from Biomass-Burning Rural and Non-BiomassBurning Urban Households in North-eastern China. Environmental Health Perspectives, 116(7): 907-914.

Lim W. Y. and A. Seow 2012.Biomass fuels and lung cancer. Respirology, 17: 20-31

*Moghissi, A.A. 1991.Strategies for Development of Indoor Air Quality Standards.Environment International,17: 365-370.

*Mohan, J., A. Gadgil and N.J. Pawar 1992. Indoor air quality assessment atselected locations in Pune city.Indian Journal of Environmental Health, 34(3): 209-213.

Murray, E.L., L. Brondi, D. Kleinbaum, J.E. McGowan, C. Van Mels, W.A. Brooks, D. Goswami, P.B. Ryan and M. Klein 2012. Cooking fuel type, household ventilation, and the risk of acute lower respiratory illness in urban Bangladeshi children: a longitudinal study. Indoor Air,22(2): 132-139.

Rollin, H.B., A. Mathee, N. Bruce, J. Levin, and Y.E.R. Von Schirnding 2004.Comparison of indoor air quality in electrified and un-electrified dwellings in rural South African villages. Indoor Air, 14: 208-216.
*Smith, K.R., J.M. Samet, I. Romieu and N. Bruce 2000."Indoor air pollution in developing countries and acute lower respiratory infections in children."Thorax, 55 (6): 518-532.

Smith, K.R. and S. Mehta 2003. The burden of disease from indoor air pollution in developing countries: comparison of estimates. International Journal of Hygiene and Environmental Health, 20: 279-289.

Smith K.R., S. Mehta, M. Maeusezahl-Feuz 2004. Indoor smoke from household solid fuels. In: Ezzati M, Rodgers $\mathrm{AD}$, Lopez AD, Murray CJL (eds) Comparative quantification of health risks: Global and regional burden of disease due to selected major risk factors, World Health Organization, Geneva. 2: 1435-1493.

Warwick, H. and A. Doig 2004. Smoke - The Killer in the kitchen: Indoor Air Pollution in Developing countries. ITDG Publishing Southampton Row, London, UK: 39.

World Health Organization 2006.Fuel for Life Household Energy and Health.WHO Press, Geneva, Switzerland.

World Health Organization 2007a. Indoor Air Pollution Takes Heavy Toll on Health, Geneva, Available at:http://www.who.int/mediacentre/news/notes/2007/np20 len/index.html

World Health Organization 2007b.Indoor air pollution and lower respiratory tract infections in children.WHO Press, Geneva, Switzerland. 